\title{
TRANSFORMACIONES EN EL LENGUAJE DEL TEATRO DE ANIMACIÓN¹
}

\author{
Valmor Níni Beltrame ${ }^{2}$
}

RESUMEN: El teatro de animación en Brasil conquisto, a partir de los años de 1970, un nivel de madurez diferenciándolo de las prácticas predominantes registradas en los años anteriores. Ciertas evidencias crean la posibilidad de afirmar que esta arte, antes homogénea, se torna mas hibrida y combinada. Hay un visible cambio en el vocabulario y en las nomenclaturas que definen esta arte, se rompe con el espacio de representación, el teatrino y el titiritero que antes actuaba escondido pasa a interpretar delante del publico, la creación colectiva da lugar a lo que se llama de dramaturgia colaborativa, el trayecto de los grupos en las ultimas décadas apunta para la inexistencia de una poética predominante en este lenguaje, pero remete a las micropoéticas creadas en el interior de los grupos de teatro de animación. La investigación que actualmente realizo titulada "Teatro de muñecos transformaciones en la poética del lenguaje", pretende analizar los principales cambios ocurridos en esta arte en Brasil. En este texto discuto la existencia de diferentes modos de creación del espectáculo teatral, un de los ejes de análisis de la investigación.

PALAVRAS-CHAVE: Teatro de Animación; Dramaturgia Colaborativa; Creación del Rspectáculo Teatral.

El teatro de muñecos brasileño sufrió grandes transformaciones en los últimos cuarenta anos. Ha dejado de ser un arte destinado exclusivamente para niños y ha superado la visión de cronistas, historiadores y viajeros que recorrían el Brasil en el siglo XVIII y consideraban el teatro de muñecos "una ingenua diversión del pueblo" (BORBA FILHO: 1987:56).

La lucha por el reconocimiento y la valorización de este género de teatro es sostenida por grupos de distintas regiones de Brasil, sumada a la presentación de espectáculos de alta elaboración técnica y artística, contribuyen para superar las visiones estereotipadas sobre su lenguaje. Las oportunidades para reflexión proporcionadas durante los eventos de la Asociación Brasileña de Teatro de Muñecos en los festivales de teatro de muñecos organizados en varias regiones;

\footnotetext{
1 Comunicação apresentada no XVII Congreso Internacional de Teatro Iberoamericano y Argentino, realizado de 5 a 9 de agosto de 2008 em Buenos Aires. Organizado pelo Instituto de Historia del Arte Argentino y Latinoamericano "Luis Ordaz", Facultad de Filosofía y Letras de la Universidad de Buenos Aires.

${ }^{2}$ Professor Doutor do PPGT - Mestrado em Teatro/ CEART-UDESC.
} 
las actividades relacionadas a la formación, tales como la inclusión de disciplinas especificas en las universidades, y las iniciativas de publicar estudios y investigaciones académicas sobre teatro de muñecos han ayudado en ese proceso de cambio.

Brasil es uno de los pocos países donde el teatro de muñecos practicado por artistas del pueblo aun se mantiene vivo. En algunos locales de la región nordeste del país, especialmente en Pernambuco, existe una forma de teatro de muñecos conocida como mamulengo. Los mamulengueiros con hombres simples, pobres y generalmente analfabetos. Sin embargo, son conocidos como "Maestros". Los artistas que realizan este "juego" son los que crean, conocen y perpetúan los 'saberes' de su arte (SANTOS: 1979:58).

La continuación y preservación del mamulengo están íntimamente unidas a la transmisión oral y, sobre todo, a la observación de la práctica, a la forma de representarlo. Lo que es transmitido a los aprendices del mamulengo puede ser comprendido como técnicas, o "estructuras materiales y imaginarias" o todavía como "técnicas codificadas de larga duración. Para Eugenio Barba (1995:19), estas prácticas artísticas van construyendo un acervo de procedimientos y concepciones incorporadas por maestros del oficio, y constituyen un "conjunto de buenos consejos" a los cuales el aprendiz recorre y hace uso.

Se puede percibir que hoy, la creación de espectáculos de teatro de animación incorpora una gran variedad de recursos, distintos lenguajes y procedimientos que lo vuelve heterogéneo e hibrido. La proximidad con otros lenguajes artísticos, tales como la danza, la mímica, el circo, el espectáculo multimedia, entre otros, vuelve este género de arte reconocidamente más contemporáneo, conduciéndolo hacia un camino que lo acerca a otros campos de las artes teatrales y visuales, disminuyendo las fronteras entre sus distintos lenguajes

Eso es el resultado de la variedad de medios de expresión, de haber dado espacio a otros tipos de muñecos distintos del antropomorfo, de la ruptura con el escenario tradicional del teatro de títeres y de la presencia visible del actoranimador en la escena.

Estos cambios son igualmente visibles en las nomenclaturas utilizadas para denominar este arte. Hasta los años 70 este género era más conocido como 
Teatro de Títeres, Teatro de Fantoches o Teatro de Marionetas. Luego se le comenzó a denominar Teatro de Muñecos. Posteriormente se le llamó de Teatro de Formas Animadas y recientemente de Teatro de Animación. El uso de cada una de esas expresiones revela distintos modos de concebir este arte. Sin embargo, en todas ellas estará siempre presente lo que más fuertemente la caracteriza: la presencia de la forma animada por el actor-animador del Teatro de Muñecos.

Es aquí donde se encuentra el gran desafío de ese artista: animar la forma inanimada, pasar sus emociones al objeto, hacer la transfiguración de un objeto aparentemente inerte en personaje. El complejo trabajo del actor-animador consiste en establecer la comunicación con el publico exhibiendo un personaje que no se presenta en su cuerpo, pero si en el objeto. Su relación con el público se hace por medio de un objeto al que debe animar.

Hoy existen distintas formas de creación del espectáculo teatral, pero es interesante resaltar la existencia de, por lo menos, tres ejes que guían ese proceso. Al evidenciar tres facetas de la creación de espectáculos de teatro de animación contemporáneo, no quiero afirmar que esas sean las formas más recurrentes. Estas facetas son importantes porque revelan la existencia de trayectorias distintas en la manera de crear y además, comprueban la madurez y el desarrollo de esta arte que son:

a) la re-creación de lo regional/popular - la apropiación de elementos de la cultura regional/popular en la puesta en escena de espectáculos de teatro de muñecos no es un fenómeno reciente. Desde los anos de 1960 y 1970 esa práctica es muy común. Algunos elementos que guiaban la creación de espectáculos en aquel tiempo, aun se utilizan actualmente, como por ejemplo, la re-creación de mitos, jolgorios y dichos de la gente. Desde aquel tiempo, los espectáculos que se mantienen vivos y provocan repercusión, son los que, en lugar de transponer expresiones populares para el escenario, las re-crean, reinventan, incluyendo elementos que universalizan el espectáculo y amplían las fronteras del sentido y de la comprensión regional.

La novedad en esa práctica es el hecho de contribuir para el fortalecimiento de "identidades", transponiendo los límites de lo que podría configurar como espectáculo basado en la cultura local, como algo pintoresco o exótico. 
Personajes conocidos localmente y que se encuentran vivos en la rica tradición de espectáculos como el mamulengo, por ejemplo, están vivos en las presentaciones de varios grupos y colaboran para construir identidades, el sentimiento de pertenencia, que se va delineando y realizando en la conducta de los personajes y en la poética del los espectáculos.

La idea de la "diferencia" que penetra en la manera de ser de esos personajes y del universo donde se encuentran, son sentidos y tratados como elementos que forjan una modo de ser, un modo distinto de ver y estar en el mundo. El modo de crear esos espectáculos deja claro que no existe una cultura, pero muchas culturas. $\mathrm{Y}$, de ese modo contribuyen para que se comprenda la existencia de un pluralismo cultural.

Un dato nuevo presente en ese modo de crear espectáculos surge también en la conducta de directores y dramaturgos que actúan como "re-aprovechadores y re-definidores de expresiones". Al apropiarse de elementos de la cultura para crear, demuestran que elementos de la cultura local pueden ser universales, pues tocan en los elementos más fundamentales del ser humano.

b) la dramaturgia des-construida o la escena fragmentada - Ese procedimiento nace del deseo de ruptura con las formas tradicionales de creación del texto o trama. Ya no interesa la dramaturgia tradicional, la obra "bien hecha", aquella con inicio, medio y final. Es un tipo de proposición ofrece pocas informaciones, para estimular al espectador a componer su propio rompecabezas, cujas piezas se presentan poco a poco para que cada espectador pueda formar su cuadro dentro de su imaginario. La idea de que el espectador puede, el propio, a partir de los estímulos que recibe, crear una narrativa propia, cuenta con la participación de la emoción durante el espectáculo.

El trabajo de construcción dramatúrgica consiste en andar por nuevos caminos, distintos, donde el tema central es el principio conductor. Se niega el texto racionalista, la idea de que el conocimiento y la experiencia significativa son posibles únicamente por medio del pensamiento lógico, del discurso verbal y del intelecto. Por eso, otra característica innovadora de esta proposición es utilizar pocas palabras, el texto verbal pronunciado.

La eliminación de palabras, el decir con acciones y gestos, la acción destituida del habla exige un trabajo cuidadoso en la selección de las imágenes, 
además de gran clareza de gestos y movimientos. Exige ampliación del tiempo de ensayo para el perfeccionamiento de la escena y la construcción de la partitura de gestos, de acciones y movimientos que definen la dramaturgia.

Las obras no presentan tan solo la situación principal, un conflicto central, o un personaje protagonista. Predomina la definición de un asunto, el tema, sobre el que giran las situaciones, acciones e imágenes. Pero ocurre también la yuxtaposición de escenas sin relación aparente además de imágenes y acciones inconexas.

La ruptura con la narrativa linear, la narrativa con inicio, medio y final, para contar una historia, donde cada ocurrencia es la secuencia de la acción anterior, es reemplazada aquí por una proposición narrativa des-construida, desordenada. Situaciones que por momentos presentan una secuencia pero, que luego a seguir son abandonadas, interrumpidas par una imagen en movimiento y que hace con que el espectador imagine, reflexione o simplemente disfrute de la belleza de la imagen, contrastan con los tipos de espectáculos exhibidos en otras épocas.

c) la intertextualidad - otro camino que caracteriza una forma nueva de creación del espectáculo puede ser definida par intertextualidad. Se trata de un procedimiento que busca en fuentes existentes, los datos y elementos que hacen parte del texto o de la escena.

Del punto de vista de la dramaturgia, eso significa elegir trozos de textos de distintos autores, no siempre textos dramáticos, y que son colocados de un modo que brindan un nuevo sentido, muchas veces distintos de la intención con las que han sido originalmente concebidos. La unidad temática es formatada por el dramaturgo o director que, al utilizar materiales ya existentes, asume la posición de "colector" y, con frecuencia utiliza el recurso del collage y negligencia la secuencia lógica de ideas.

Del punto de vista del texto, intertextualidad es entendida como "todo texto que se construye como un mosaico de citaciones, y como absorción y transformación de otro texto" (Kristeva Apud RÖHL, 1997:29). Pero, ese procedimiento se caracteriza también por la interface con otros lenguajes artísticos, tales como la danza, las artes plásticas, las imágenes grabadas y filmadas, que producen sorpresas, dudas y algo de distanciamiento en el público. Para Cohen que prefiere la expresión "intertextualidades", esas ocurren "entre la 
palabra, las materialidades y las imágenes; en las formas antes que en los sentidos, en las poéticas deseantes que brindan flujo a las corporalidades, a las expresiones del sujeto en los paisajes del inconsciente y en sus mitologías primordiales" (2001:106). Son espectáculos a que abandonan el gueto del muñeco (especialmente el muñeco del tipo antropomorfo) y utilizan formas, objetos, imágenes que se distancian de los registros o la han vuelto conocidas del gran público.

En esta modalidad de trabajo, es interesante observar que, la identificación del público con el espectáculo también ocurre en la medida en que reconoce o recuerda los trozos de textos de autores conocidos, presentes en la dramaturgia.

Se debe resaltar que estas facetas que caracterizan algunos procesos de creación de espectáculos son cambiantes y están en permanente movimiento y con frecuencia se interpenetran y muchas veces se vuelven menos o más visibles.

Los espectáculos de teatro de animación representan actualmente distintas tendencias con trayectorias diversas en su modo de crear. Pueden ser identificadas, en ciertos momentos como teatro de muñecos tradicional, aquel conocido a fines del siglo XVIII, y en otros momentos se identifican con trabajos que se acercan a ideas de heterogeneidad e hibridismo, más características del la contemporaneidad. Mientras algunos trabajos se inspiran en técnicas y principios centenarios, otros buscan comunicarse con el público utilizando recursos más actuales. Lo importante es constatar que bajo el vasto campo del teatro de animación hay espacio para todas las tendencias, sin jerarquizar su importancia o su valor para el teatro brasileño.

\section{Referências Bibliográficas:}

BARBA, Eugenio; SARAVESE, Nicola. A Arte Secreta do Ator: dicionário de antropologia teatral. Campinas: Hucitec, 1995.

BORBA FILHO, Hermilo. Fisionomia e Espírito do Mamulengo. Rio de Janeiro: INACEN, 1987.

COHEN, Renato. Teatro brasileiro contemporâneo: matrizes teóricas e interculturalidade. In: Sala Preta - Revista de Artes Cênicas - ECA/USP. São Paulo, N.1, 2001. 
RÖHL, Ruth. O Teatro de Heiner Müller. São Paulo. Perspectiva, 1997.

SANTOS, Fernando Augusto Gonçalves. Mamulengo: o teatro de bonecos popular do Brasil. In Mói-Móin - Revista de Estudos sobre Teatro de Formas Animadas. Jaraguá do Sul: SCAR/UDESC, ano3, v3, 2007. 